\title{
"They are all Turks, but very very nice": Re-placing contemporary artists of Turkish origin
}

\author{
Lora Sariaslan $^{1}$
}

Received: 30 October 2015 / Accepted: 21 June 2016 /Published online: 29 June 2016

(C) The Author(s) 2016. This article is published with open access at Springerlink.com

\begin{abstract}
Contemporary visual artists from Turkey, who have left their 'home' for various reasons, such as migration or education, have emerged as a distinctive voice on the contemporary European art scene. What makes these artists pertinent for an analysis of new forms of identity and citizenship making, and the negotiation of belonging and mobility in contemporary Europe is that their art presents the sheer diversity of artistic approaches that address, incorporate, and fold cultural interaction as well as confrontation with the identitary and cultural 'container' that is Western Europe. This paper will focus on three cases, Nevin Aladağ, Anny and Sibel Öztürk, and Nilbar Güreș, querying whether and how their artistic gaze can provide critical insight into the diverse possibilities of relations between Turkey and Western Europe. Using their works as laboratories or 'snap shots' of identity negotiations, this paper will query how mobility and transnational encounters shape artistic production, and how, in turn, such transnational and intercultural works can shed new light on the making of contemporary European identities 'beyond borders' that integrates Turkey through art.
\end{abstract}

Keywords Contemporary art · Mobility · The other . Transnational identities $\cdot$ Turkey and Europe

Lora Sariaslan

lora.sariaslan@gmail.com

1 University of Amsterdam, Spuistraat 134, 1012

VB Amsterdam, The Netherlands

\section{Introduction}

Recent years have witnessed the emergence of art produced by a number of international artists who travel widely to create and exhibit their work, much of which derives from their experience of homeland, migration, and encounter. Yet, as Kitty Zijlmans notes, these 'immigrant-artists' are facing a vacuum in the art world, for all too frequently they are only connected to the country of origin and their art is confined to their alleged original culture [1]. One such group of artists, contemporary visual artists from Turkey, who has left 'home' for various reasons such as migration or education has emerged as a distinctive voice on the contemporary European art scene. What makes these artists pertinent for an investigation of new forms of identity and citizenship making, and the negotiation of belonging and mobility in contemporary Europe is that their art is a means to present the sheer diversity of artistic approaches that address, incorporate, and fold cultural interaction as well as confrontation with the identitary and cultural 'container' that is Western Europe. Starting from the concept of the Deleuzian 'fold,' the artists represent both personal and societal memories, recalling, retracing, and giving a renewed presence to the past through their depictions and representations. Deleuzian fold can be seen as a model for analyzing contemporary arts. There is a variety of modalities of folds - from the fold of our material selves, our bodies - to the folding of time, or simply memory. Indeed subjectivity might be understood as precisely a topology of these different kinds of folds. This gives the fold an explicitly ethical dimension, but also a political one, for as Deleuze remarks the emergence of new kinds of struggle inevitably also involves the production of new kinds of subjectivity, new kinds of fold. Art here is the discovery of new combinations - new ways of folding the world 'into' the self, or, more simply, new kinds of subjectivity [2]. This paper 
adopts art as 'snap shots' of identity negotiations and queries how mobility and migration shapes artistic production, focusing on case studies that can shed light on the making of new intercultural European identities through the folding of art.

Officially starting with bilateral recruitment agreements in 1961, the influx of guest workers was initially a business transaction between states, which originally aimed at recruiting a foreign work force for Germany, Austria, and the Netherlands for a limited period of time with the notion that they would be 'guests' and eventually return to their country of origin. However, this 'transactional migration' in post-war Europe transformed all the countries involved economically, politically, socially, psychologically, and artistically as the duration of stay went beyond the desired period, and as the 'guests' brought over their families, and settled in their new 'homes' [3-11]. What is of specific interest is how migration with its results as a social and economic phenomenon has recently been represented through the prism of contemporary art.

Both migration and artistic practice are far from a uniform or evenly shared experience. Therefore, I would like to focus especially on three cases, coincidentally all female: Nevin Aladağ, Anny and Sibel Öztürk, and Nilbar Güreş in order to present their artistic gaze into the diverse possibilities of European identities and their implications. How do their transnational experiences affect the art practice? Can artistic production be a form of individual emancipation? How is cultural confrontation translated into an artistic interpretation? What is lost (or gained) in this 'encounter' and how does art become a reflection of mobility and belonging? These questions are intimately linked to the experience of migration both on an individual level, as well as a part of a larger cultural ecology with its aesthetic, artistic, social, economic, political, and transformative dimensions. What the chosen artists hold in common is the fact that while they might otherwise have remained 'invisible' or have been categorized as 'other, worker, alien, stranger, and/or trespasser,' they have created their identity through art. How is art used for cultural confrontation? Their work speaks of the connection between the countries and becomes a reflection of a wide range of issues. Art generates a private and public recognition for these individuals and invokes a new form of citizenship based on art-a citizenship that both defines a new identity, but can also be the basis for agency and life strategy. It is through art that they are able to present and claim their identity both in Turkey and Europe.

Indeed, these artists can be seen as a prism for understanding the hybrid constellations and negotiations of migrant identities in Europe (and the world) today. As Nilüfer Göle writes "constellations bring together seemingly unrelated events, separated in time and in space, and therefore create a new space of interpenetration and collusion, which affects the course of change and meaning of the modern" [12].
Furthermore, as Arjun Appadurai has argued in his book Modernity at Large, migration and its associated cultural products create what he terms a "new order of instability in the production of modern subjectivities" [13]. The artists I examine in this article can be seen as key actors in making this new, 'unstable' order, creating precisely what Appadurai calls "diasporic public spheres, phenomena that confound theories that depend on the continued salience of the nation-state as the key arbiter of important social changes" [13]. As these artists become representatives in this change, through their art they initiate a constellation that signifies a new transformative order.

\section{Nevin Alada $\breve{g}$}

The discussion of cultural identity and confrontation with its societal and artistic role has certainly lost none of its urgency. As the first case, I would like to concentrate on Nevin Aladağ. Her artistic practice covers a diverse range from photographs, video, site-specific installations to performances. Born in Van in the eastern part of Turkey in 1972, a year later she moved to Germany with her family, and later studied sculpture at the Academy of Fine Arts in Munich. In 2002, she moved to Berlin to complete her residency at Künstlerhaus Bethanien. Of the three cases here, she best exemplifies the Gastarbeiter (guest worker) background. Aladağ neither ignores nor openly battles against this fact and its reception dilemma: she integrates this as a strategy in her works, engaging the viewers from their own stance of expectations, and at first glance gives them 'what they are looking for'. For instance, in deutsch, türk, kurd (2003-2004) (Fig. 1), the artist creates white tshirts with silk printed patterns of her three identities written in the international Braille language. Her identity is composed of numerous 'folding's. All that she 'is' is laid bare, and made visible and even tactile.

On this basis, she enables viewers to first gain access to other ways of interpreting. This productive confusion is inherent in many of her works, as we stand in front of carpets whose spatial subdivision is based on a basketball game that has very little to do with the supposed cultural authenticity of the carpet. She creates cross-pollination of traditional motifs with basketball. These are the moments in which Aladağ returns the ball of the identity discourses to their real addressee, the Eurocentric as well as the Turkish viewers.

Nevin Aladağ's training as a sculptor may have heightened her sense of the limits and the boundaries of the objects or the identity of forms. All of her projects reveal a subtle analysis of the rules of the spatial environment in which the work takes place. This may be why many of her projects take on the character of signs or gestures in the urban fabric, the kind that evaporate and pass. The ephemeral nature of the acts she produces is at odds with common notions of identity as a given condition, doxa. She takes the doxa and playfully represents it 


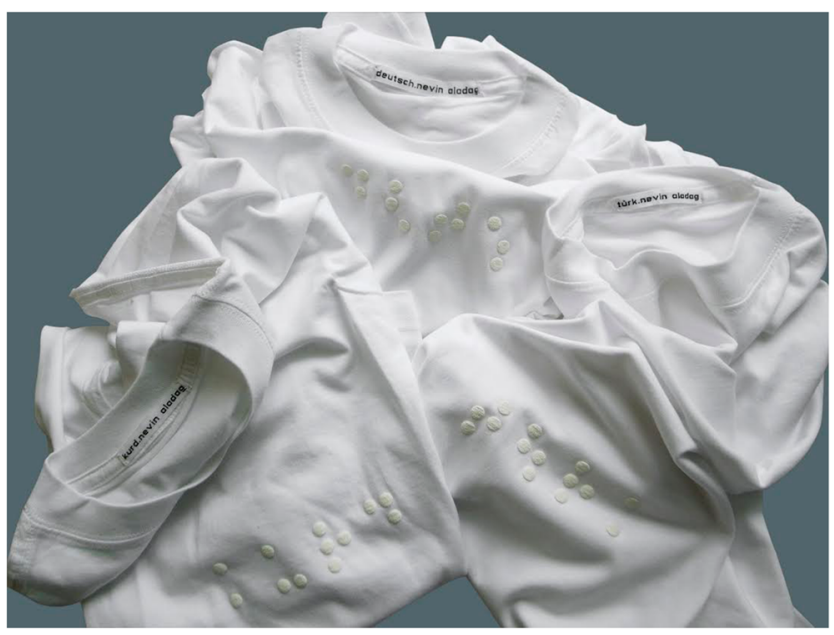

Fig. 1 Nevin Aladağ, deutsch, türk, kurd, 2003-2004, T-Shirt edition of 99, Courtesy of the artist, Rampa (Istanbul) and Wentrup Gallery (Berlin)

to the viewer. She gracefully 'folds' numerous matters into her work.

Aladağ delegates her performances, and often they are 'acted out' in terms of popular cultural practices related to group identity, such as those of migrant communities or social class or both at the same time. Urban space is what interests Nevin Aladağ in her work - as a space for negotiation and representation of different agendas, as a space full of traces and poetry, and as a space where the individual and community meet up over and over. In this spirit, her performances have been staged on streets, in apartments, on a roof, and in a Berlin courtyard. As an image of close co-existence, the courtyard can be viewed in general terms as a micro-unit of public space. Taking this as her theme, Aladağ went on walks in Berlin (2009), Vienna (2010), and Hamburg (2010) to research her performance Hochparterre (Mezzanine) (Fig. 2). It takes place in the courtyard of Naunynstrasse 27 in Kreuzberg, the district with the most culturally diverse population in Berlin, a great example for 'super-diversity'. As Steven Vertovec explains 'super-diversity' is "not just in terms of bringing more ethnicities and countries of origin, but also with respect to a multiplication of significant variables that affect where, how, and with whom people live" [14]. The notion of 'super-diversity' is the core of this artwork represented by the interplay of various factors such as different migration statuses and their concomitant entitlement, discrete gender and age profiles, and mixed local area responses by residents, which are rarely described side by side. Although 'super-diversity' and 'hybrid identities' are distinct concepts and literatures, they can be usefully brought together to understand the artistic practice of Nevin Aladağ.

In Hochparterre (Mezzanine) we see a sofa and a living room lamp. They are angled towards a mezzanine floor window hung with curtains conspicuously installed not inside but outside. In this semi-public domain that plays with interior and
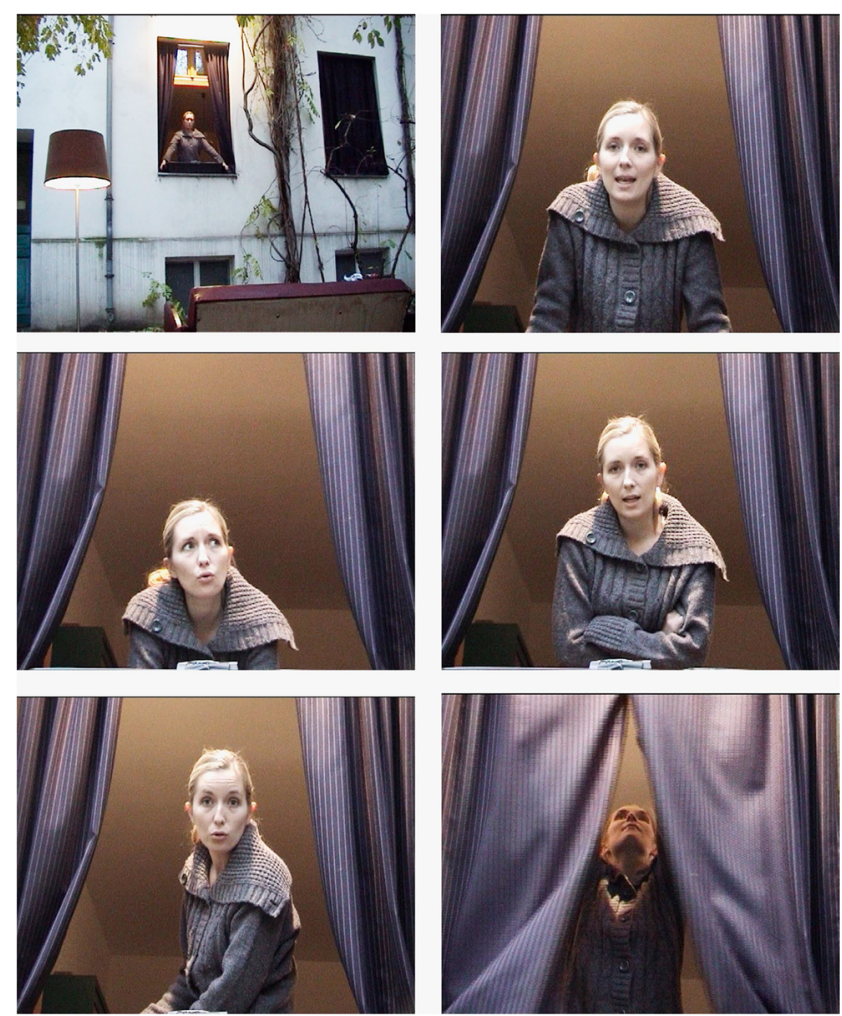

Fig. 2 Nevin Aladağ, Stills from Hochparterre, [Mezzanine], 2009, Performance, Ballhaus Naunynstrasse, Berlin, Performance duration 9 min, actress: Joanna Praml, HD video, 9 min, Courtesy of the artist, Rampa (Istanbul) and Wentrup Gallery (Berlin)

exterior, a young blonde woman appears at the window. As soon as she has pushed the curtains aside, she starts moving her lips and reenacting each resident's identity through an edited collection of interviews with people living in the neighborhood heard from the loudspeakers. There are young Turks sighing about disadvantaged Germans, followed by longtime residents complaining of the lack of proper beer bars where one can 'still smack the waitress on the butt, if she lets you'. The actress Joanna Praml does not miss a second within this nine minute-long performance of lip syncing and acting all these roles, switching between brash and insolent, shy and forward, male and female, young and old. She lip syncs different languages while leaning out of an open window on the elevated ground floor, unifying the diverse views expressed by the neighborhood, from the Turkish migrant who says, 'It's not that nice here, but we got used to it. Of course, it's not like your home country, but we got used to it,' to statements such as 'They are all Turks, but very very nice.'

Nevin Aladağ creates an audiovisual portrait of a multiethnic quarter.

Taking us on a labyrinthine trajectory, this rich multivoiced assemblage, because it is figured in the body and voice of one person, does not risk being perceived as stereotypes of calcified ethnic or cultural traits. Aladağ 
instead reflects on the difference within the supposed sameness, the heterogeneity in the homogeneity. Hochparterre does not try to take the community as a referential social entity. What it has done is to reveal the impossibility of community and the impossibility of total consolidation, wholeness and unity. Aladağ's work reminds us that the postcolonial subject is not simply a way of representing difference but a process of negotiation in which self and experience are never totalized and always ongoing [15].

The result is a multi-vocal and multi-layered poetry of the city, in which the spectator, actress, and generators of the original soundtrack become actors of a play centered on authenticity and reality. The various answers given by the participants (living in the neighborhood) form an examination of the possibility of drawing boundaries and designating identities, creating a new encounter and cocktail of dissonant, at times, contradicting voices without unifying these contradictions into a harmonic and nostalgic picture. Who lives in the neighborhood? Are they glad they are there? What do people think of each other? Hochparterre presents the answers, because it invites the street itself to speak.

The performances in Berlin, Vienna, and Hamburg reflect the real conflicts of (in this case) German-speaking neighborhoods facing issues of the foreign, the new, and change - as well as revealing secret desires and unexpected viewpoints. Those interviewed all speak their own words, but their polyphony is edited into a single entity. By projecting subjectivity onto a multiplicity of voices, processes of identity formation-based on experiences, encounters, wishes and desires, achievements and plans - are renegotiated within a social context. In her performances, Aladağ creates artistic frameworks for experience that reflect and dramatize aspects of the structures and conditions which form personalities and communities, raising questions that unsettle and intrigue, confuse and delight us. In her diverse artistic praxis, she brings together moments of poetry, physicality, and surprise that shape her aesthetic reflection on the world, life, and art, and which have a tendency to enchant her audience.

\section{Anny and Sibel Öztürk}

The subject of Gastarbeiter creates the crux of Behind the Wheels by Anny and Sibel Öztürk. In the installation Behind the Wheel (2003), the sisters depict the annual trips back to Turkey. The older model Mercedes Benz with Offenbach license plate is in the exhibition space, with its rooftop luggage carrier packed with suitcases and a rolled up carpet. The vehicle's interior is decorated with streamers, doilies, blankets and pillows. One can hear music alongside voices and laughter that remind us of the absent travelers. With maps illustrating the route, drawings (gouaches of moments in the journey), texts on the walls (speaking of longing for the grandfather, the south, the sea), this story tells of the communal experience among the Gastarbeiter, in Germany presenting us a (re)creation of an annual journey between these two countries. Through this work, the Öztürk sisters turn their family trips into a collectively shared experience and memory, and their experience and memory into an art installation.

Although Behind the Wheel might be viewed as a typical work created by the daughters of guest workers, it is an exception as the two sisters Anny and Sibel Öztürk have a rather different (hi)story. Anny was born in 1970 in Istanbul and her sister Sibel in Eberbach am Neckar in 1975. As Anny and Sibel recall:

Our parents left for Germany in 1972. Their decision was made more from a desire for adventure, wanderlust. Both journalists, well off and with one child, they set off to see the world. They did not go to make money. They went to experience something new [16].

Both sisters grew up in Germany and studied at the Städelschule in Frankfurt. When Anny is asked of how being born in Istanbul and spending most of her life in Germany has influenced her art, she responds:

My home is in more than one culture, this fact is reality for a huge amount of Europeans and by no means an exception. This has a big influence on my work and on the collaboration with my sister Sibel. Many of our works are based on memories. Most of them refer to shared familiar memories. Therefore we have reference fields whose character differentiates in a cultural context, Germany and Turkey. Both are inextricably linked with each other [17].

What the sisters do on a personal level is to record and present their memories and subjective experiences which constitute the basis of the work, and on a general level, the work connects simultaneously with the artistic and non-artistic communities in-and-between these countries, as this is a vision commonly experienced during the summer holidays. Behind the Wheel takes the actual mobility of the Gastarbeiter, folds and presents it back to us. The cliché of the Gastarbeiter family; an image of the Turkish worker and his family going back to the 'motherland' is in front of our eyes. The Öztürk sisters give an artistic visibility to this journey and its participants although they are physically absent. But where does Turkey stand for these artists? How do they 'fold' Turkey into/with Germany? Anny Öztürk responds:

Our connection to Turkey is strong... in our hearts. The language I use when thinking, dreaming, and speaking is German. My Turkish is more of a foreign language. I 
always want to live in Germany, but I want to be buried in Turkey with my ancestors, with my family [17].

Through their work, we can see how migrants transform geographic and cultural boundaries, how such 'travels' potentially change and challenge presupposed understandings of identity.

\section{Nilbar Güreș}

Nilbar Güreș is the third example through which we see how the Turkish artists work with their own image, and their perceived image: a meta image. Güreș (born 1977 in Istanbul) lives and works in Vienna and Istanbul. Her biography is relevant here as she moved from Istanbul to Vienna in 2000 at 23 years old. She received her BA in Painting from the Faculty of Fine Arts, Marmara University, Istanbul, and then completed her MA in Painting \& Graphics from the Academy of Fine Arts, Vienna. As an artist who got her preliminary artistic framework and education in Istanbul and later in Vienna, her work is inspired by her daily experiences and observations [17]. She works with various media including drawings, collages, objects, videos, photos, and public space performances.

Nilbar Güreş’ first video works, Soyunma (Undressing) and Yabancl (Stranger) (both from 2006), deal with women, identity, and dress codes as they relate to issues such as nationality, ethnicity, and class. Stranger is composed of four videos that are three minutes each. The focus will be on the first and last videos that make up Stranger. The first video, Person of Cloth (Fig. 3), depicts a woman on the Vienna subway wearing a blue and red floral print that totally covers her face and body, topped by a black headscarf with embroideries on its edges (worn in the style of villagers in Turkey). ${ }^{1}$ As the camera shows both the protagonist and the wagon that she is in, we see that she is sitting with her legs crossed in the subway and the only one who pays attention to her is a boy, who cannot stop watching her (Fig. 4). Some stare but most ignore her, and as the announcement for the next stop is done in German, she remains unperturbed, only sometimes shifting and looking around. In another instance, she is literally perched on the seat next to a man, she looks around her, and the camera zooms on her face and the video ends with her facial close up. Nilbar Güreș visually creates 'a foreigner, an isolated migrant' using textile - a female prescribed medium - in an environment that only seems to represent ignorance and invisibility.

\footnotetext{
${ }^{1}$ According to Gökarksel and Secor [18] "There are over half a dozen ways to refer to the unpinned headscarf, the scarf tied under the chin. This style can be referred to as mother's style, grandmother's style, aunt's style, Ottoman style, Anatolian style, Republican style, and Kemalist style, implying that the style is for older women and reflects an outmoded set of norms associated with rurality, tradition, and the secular republic".
}

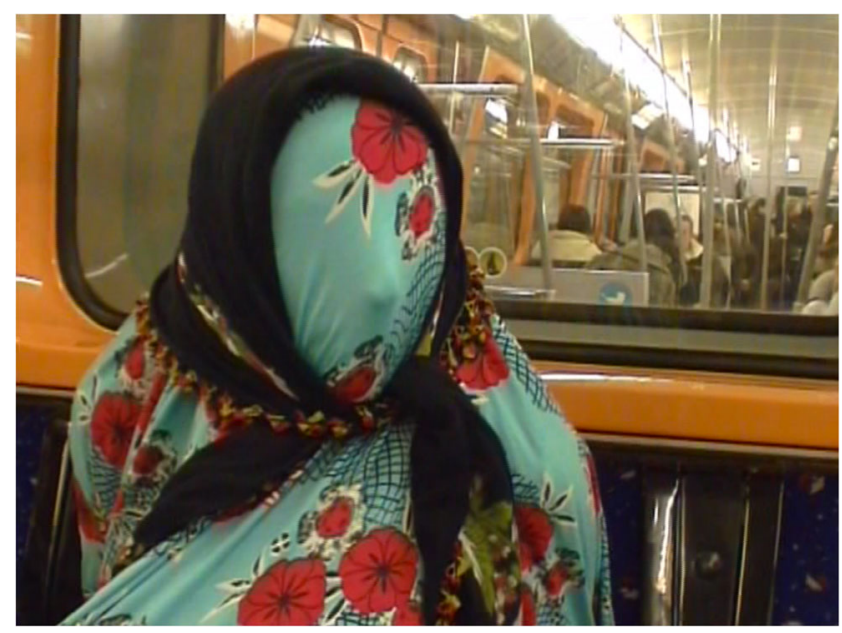

Fig. 3 Nilbar Güreș, Still from Person of Cloth from Stranger (Yabanc1), 2006, Video, $12 \mathrm{~min}$. (each video $3 \mathrm{~min}$.), Made up of 4 videos (Person of Cloth, Mirror, Turk Head, Stairs), Courtesy of the artist, Rampa (Istanbul) and Galerie Martin Janda (Vienna)

Though we, as the viewer, know that it is the artist that is the protagonist, there is no way of knowing the person's gender, as the textile and the manner in which she is sitting down do not give away any clues. Even the couple that sits across from her do not 'see' or 'engage with' her. There are two layers in the audience. The first audience is the fellow passengers on the subway traveling along with the artist. The second audience is us, watching the video. The artist wittily turns the first audience or the 'non-lookers' into actual characters in her work as she uses the public space for a different purpose. People are not turning their faces away, they are either completely ignoring her, or looking to understand what exactly is unfolding in front of their eyes. Their lack of response or eye contact present the attitudes, stereotypes, and prejudices that govern life.

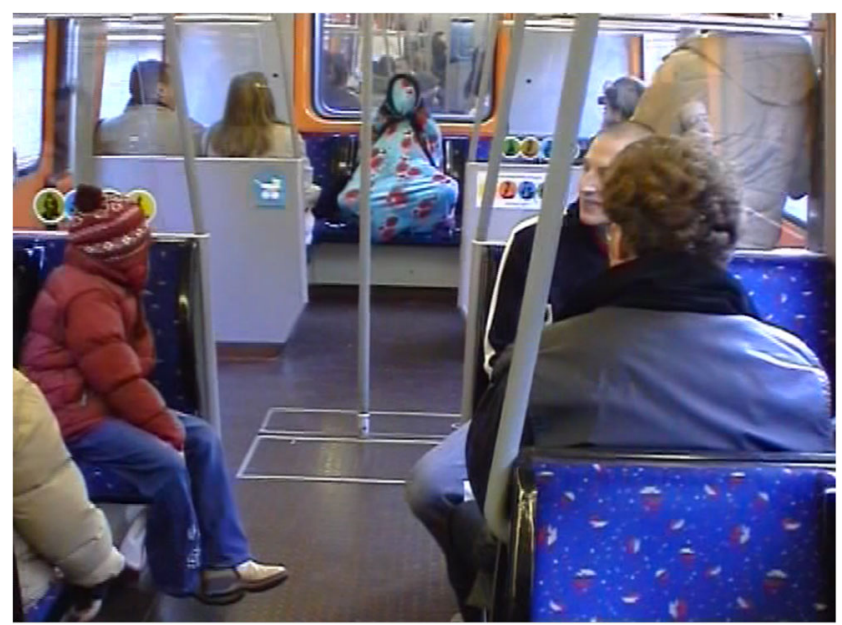

Fig. 4 Nilbar Güreș, Still from Person of Cloth from Stranger (Yabanc1), 2006, Video, $12 \mathrm{~min}$. (each video $3 \mathrm{~min}$.), Made up of 4 videos (Person of Cloth, Mirror, Turk Head, Stairs), Courtesy of the artist, Rampa (Istanbul) and Galerie Martin Janda (Vienna) 
As Claire Bishop notes:

Artists choose to use people and themselves as material for many reasons: to challenge the artistic criteria by reconfiguring everyday actions as performance; to give visibility to certain social constituencies and render them more complex, immediate and physically present; to introduce aesthetic effects of chance and risk; to problematize the binaries of live and mediated spontaneous and stages, authentic and contrived; to examine the construction of collective identity and the extent to which people are always exceed these categories [19].

In her current practice, Güreș uses fabric in a myriad of ways from her collages to her videos. The fabric has a twosided mission, both of veiling and revelation. The textile that covers her in the video, also makes us wonder how claustrophobic and breathless she must be underneath it, with no open hole in the textile the artist is completely wrapped in it. As Güreş covers herself, she uncovers a silent prejudice. It is not only the fabric that covers her body, but also a social fabric, as dressing and undressing are fundamentally codes. Maybe not only undressing herself, but most importantly the desire to undress the male hegemonic system in Turkey, and at the same time undressing and unpeeling the 'Turkish image' in Europe. Turkey's patriarchal rigidity seems to be covered in the soft textile. The softness of the textile becomes a buffer zone of flowery textile against patches of incomprehension [20-22].

Can art express the residue of various influences on the maker, including displacement or mobility? Autobiographical account is often part of the artwork, and the border between the artwork and the artist's biography becomes fluid, hence we might speak of a new kind of authorship, intimately related to the artist as an individual, but also mediating between home and abroad — and thus fundamental in the re-shaping of identities.

Güreş uses her body to simultaneously ironic and exemplary effect and turns herself into the work in a manner as Rirkrit Tiravanija noted, "the artist is the work" [23]. Art is being critical of the society. She is dealing with her position in society, first in Vienna, as a female, as a Turk, as an artist, and as a foreigner. She mischievously transforms and uses herself (both her past experiences and body) as the subject and concurrently the object transgressing traditional female patterns of behavior.

The last of the four episodes of Stranger entitled Stairs (Fig. 5) shows the artist going down an escalator in Vienna subway with a hood completely covering her head with an egg on a spoon in her mouth as she enters into the subway. Her gesture is a re-enactment of a children's game - the egg-andspoon race-requiring concentration and balance; its public performance by an adult here underlines the disciplining, both exterior and interior, of the woman's body as she navigates the

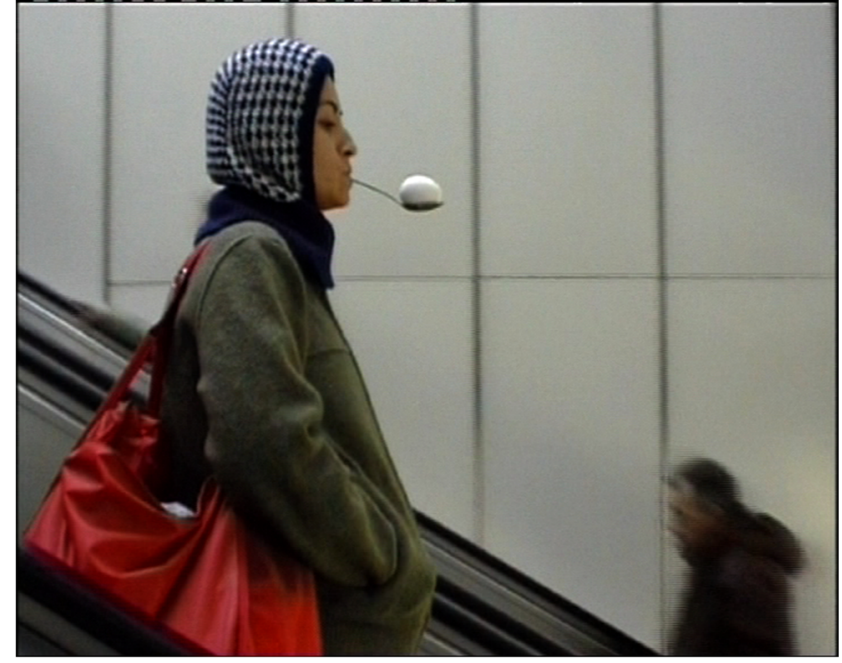

Fig. 5 Nilbar Güreș, Still from Stairs from Stranger (Yabancı), 2006, Video, 12 min. (each video 3 min.), Made up of 4 videos (Person of Cloth, Mirror, Turk Head, Stairs), Courtesy of the artist, Rampa (Istanbul) and Galerie Martin Janda (Vienna)

cityscape. A tension between marginalization and the affirmation of identity pervades Stranger, as the female body's gestures mark both a sense of indifference to what is going on around her and a self-awareness of being 'other'. As witnessed in Stairs, Güreș’ work became informed by treatment of otherness as being a 'stranger' in Austria.

As the artist moves through the subway into the wagon, she uses Vienna and its public as the backdrop to her subtle and yet in-your-face social actions (Fig. 6). The video becomes a portrait of the artist that 'folds' numerous aspects into her work: she presents how the world would like to see her-to be able to manage many things all at once, even being able to walk with an egg on a spoon in one's mouth, and to keep her

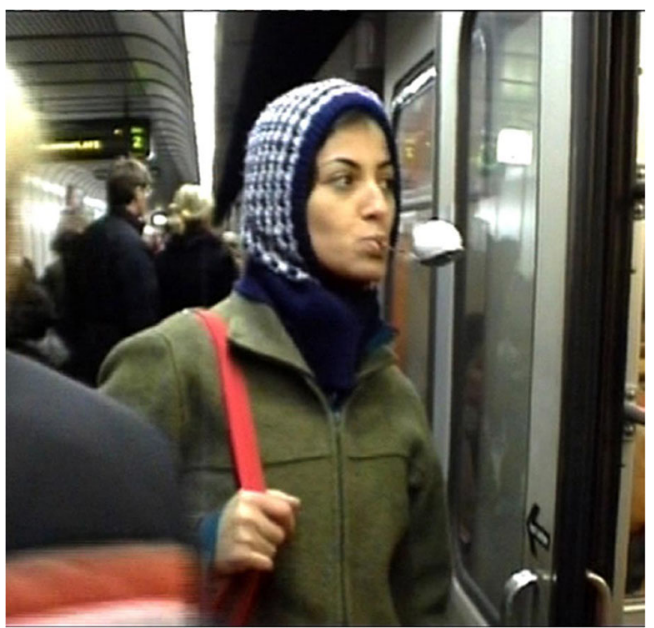

Fig. 6 Nilbar Güreș, Still from Stairs from Stranger (Yabancı), 2006, Video, 12 min. (each video 3 min.), Made up of 4 videos (Person of Cloth, Mirror, Turk Head, Stairs), Courtesy of the artist, Rampa (Istanbul) and Galerie Martin Janda (Vienna) 
poise. There is also the added layer of how she feels the western European gaze on herself. How there are certain expectations that are created and how they are not fulfilled. She focuses on criticism of social gender as well as identity politics, fluid identities, social imagination, cultural isolation, the perception of women, their presence and absence in the public arena.

The sections of Stranger video address moments of social exclusion, looking at the self-image of the excluded and the way that this distorted perception of the self contributes, in turn, to a deepening sense of not belonging. She creates 'faceless others' in willful passage or forced transit. But as people are blind to her she is blind as well, as she cannot see or encounter their reactions.

Güreş' work is (literally) multi-layered. There is the context of mobility, which rises on two levels in both of the videos. The artist's own practices of travel have informed her work, and within the work, the mobility of the subject is central. Her migration as an artist is integral to the work she produces. Her travels have informed her identification of her initial subject, her consequential choice of art forms, and the means of dissemination of the ideas they present. For Güreș, mobility is framed through specific social and spatial contexts. Also by using the medium of video, her work articulates video's most significant characteristic as a moving medium, in the triple sense - the moving image, the movement of the people, and the emotionally moving quality of the interaction, or in this case, lack of interaction, and recognition. Güreș uses the medium of our time, video, which is also the medium of time - of time manipulated, offered, and layered. Migration is also an experience of time - as multiple, heterogeneous. The time of haste and waiting, the time of movement and stagnation; the time of memory and of unsettling present not sustained by a predictable future. The phenomenon Mieke Bal calls "multitemporality; the experience of it, hetereochrony" [24]. We see how the movement of people routinely generates representations of identity in relation to difference. Coming face to face with an 'other' or 'others' lies at the heart of Güreș' work.

The anthropologist Johannes Fabian argues that 'culture' is not a situation, space, or state but a process of confrontation [25]. By calling the work Person of Cloth Nilbar Güreș poignantly points out how the others (read Austrians) view/ confront the Turks. She says that Austria, invests in arts and culture and espouses its artists, however, "an artist from Turkey is neutrally perceived as merely a woman artist. In countries like Austria and Germany, in addition to racism and enmity towards foreigners, there is an extra animosity toward Turkish people" [26]. The work can be seen as a critical voice that expresses current cultural and social developments as well as the artist's function in society and the art scene.

Güreș says that she sees her last name, which means wrestle in Turkish, as an imperative verb so that she sees it as
"Wrestle! Keep on fighting!" [27]. She simultaneously holds the subject and object of veil for discussion, as that is how the rest of the individuals in her video encounter her, and by the modulation of this tool. There is also another layer to her approach, as it stands as an artistic response to the European meta-image of the 'Islamophobic' gaze. Needless to say, within the European context, the veil signifies 'the other' and is a source of political dispute, however; Güreș takes up the veil not as a religious or national symbol but one that belongs and is assigned to women. Having never worn a veil in her life, the artist says:

In my other works, the veil also comes into the picture but in different contexts and forms, as an everyday, personal object that belongs to women, not necessarily as an object of discrimination or religious symbol. Other than that, the veil is not a big issue for me [28].

Womanhood, femininity, space, and norm are constantly interrogated through her work. What is at stake here is also the female's sexuality, which must remain hidden and even become seemingly erased or covered. The veil might be understood as the tangible correspondents of another unseeing, of an accumulation of stereotypes and cemented notion about Turkish women. It is also rather interesting to point out that Güreș is more interested in 'how the works will be read by women'. It is also this femininity that guides her artistic career in a way, as Güreș feels that she was able to study art because she is a woman, she adds that perhaps this is true of her generation, precisely because painting was seen as a sort of handicraft, thus they were able to study art.

She uses the textile to pose, on the one hand, the dialectic between a sense of belonging and identity, and, on the other, of being out of place and time. The video performance is based on the relationship between undressing and veiling as she turns the subway into a space of performativity. Her work suggests a way to foster art practices as a key component of comprehending what it means to speak, at any time, of others and us.

Working through visual metaphors and exaggeration of clichés, Güreş is working like a social researcher. She says, "in my works, I deal with certain socio-political issues rising from current identity politics, regardless of the fact that this sort of view is present in Austria, Turkey and elsewhere" [28]. The concept of folded identities allows us to better capture the identities of these artists that are not just a sum of national identities (i.e. Turkish plus something else).

Nilbar Güreș thus seeks to make the invisible visible. In her work, she presents different forms of display, through looking at the systems of representation in addition to showing her frustration with the multifarious strategies of a bodycentered rebellion. This results in the modification, enhancement, or redirection of cultural patterns of representation. 
Instead of doing a delegated performance like Aladağ, Güreș is using her own body, a metonymic shorthand for politicized identity. The living currency of her work is her body as she turns herself into a moving object in order to reject and claim certain identities and prejudices along with issues of difference, openness, tolerance, and knowledge. Güreș, as in her other works, departs from personal observations, the question of whether anything can be done, and the desire to trigger social change. She also presents the polarities of individual/ collective, author/spectator, active/passive, domestic/public, real life/art. The collaborative play before the camera results in a precise measuring out of the maneuvering space of identity, of ideas of the 'own' and the 'stranger,' as well as of the cultural shaping of images. Transgressing regimes and tactics of visibility in public space, Güreș, makes them visible and up for discussion.

\section{Instead of a conclusion}

What brings these three female cases of Nevin Aladağ, Anny and Sibel Öztürk, and Nilbar Güreş together is the fact that first of all, these artists are not rejecting or erasing the contexts, and instead, they are taking and using their background, feelings, experiences, and encounters as the source with which to create both an individual as well as artistic means to first engage the viewer and to challenge the doxa on a transnational level. Artists have become observers, and willingly or unwillingly, postulants for a redefinition of the dynamics that drive the society at large. Displacement or migration, conditions that provide a niche from which to address issues of identity as well as belonging, challenge inherited notions of home, territory, and ethnicity in a world that is constantly shifting. ${ }^{2}$ Hence, the trajectories of this select group of female artists involve not just a rethinking of the Turkish artscape, but also that of Europe, invoking a whole new transnational and transitional space within which the artist is both an author and an observer. These artists re-examine, reflect, and narrate multiple identities, geographical imaginations and experiences as their work carries traces of diverse cultures, languages, codes, traditions, and challenges. Their gaze into the new patterns of European identity not only creates a distinct constellation of art, but presents a new possibility through art. These 'new migrants' thus present 'snap shots' of how mobility, memory, and art can potentially enact different forms of new European identity with a Turkish 'fold'. Through their work, these artists present to us once again the multiple ways in which Turkey is culturally and ideationally entangled with Europe, reflecting in creative fashion on how nationhood - and Europeanness-

\footnotetext{
${ }^{2}$ For further discussions on the topic of "the new class" that these transnational artists are part of please see [29] and [30].
}

today are a continuously re-woven tapestry of different identities.

Open Access This article is distributed under the terms of the Creative Commons Attribution 4.0 International License (http:// creativecommons.org/licenses/by/4.0/), which permits unrestricted use, distribution, and reproduction in any medium, provided you give appropriate credit to the original author(s) and the source, provide a link to the Creative Commons license, and indicate if changes were made.

\section{References}

1. Zijlmans K (2008) The discourse on contemporary art and the globalization of the art system. In: Zijlmans K (ed) World art studies: exploring concepts and approaches. Valiz, Amsterdam

2. Eleuze G (1993) The fold: Leibniz and the Baroque. University of Minnesota, Minneapolis

3. Teiner V, Velling J (1994) Re-migration behavior and expected duration of stay of guest workers in Germany. Physica-Verlag, Heidelberg

4. Ercan Argun B (2003) Turkey in Germany: the transnational sphere of Deutschkei. Routledge, New York

5. McDonald S, Sonmez Y, Perraton J (2006) Labour migration and remittances: some implications of Turkish 'guest workers' in Germany. 9th Annual Conference on Global Economic Analysis

6. Gokturk D, Gramling D, Kaes A (2007) Germany in transit: nation and migration, 1955-2005. University of California Press, Berkeley

7. Kosnick K (2007) Migrant media: Turkish broadcasting and multicultural politics in Berlin. Indiana University Press, Bloomington

8. Yurdakul G (2008) From guestworkers into Muslims: the transformation of Turkish Immigrant Associations in Germany. Cambridge Scholars Publishing, Cambridge

9. Chin R (2009) The guestworker question in post-war Germany. Cambridge University Press, New York

10. Abadan-Unat N (2011) Turks in Europe: from guest workers to transnational citizens. Berghahn Books, New York

11. Nuhoglu Soysal Y (2012) Citizenship, immigration, and the European social project: rights and obligations of individuality. $\mathrm{Br}$ J Sociol 63:1-21

12. Göle N (2009) Turkish delight in Vienna: art, Islam, and European public culture. Cult Politics 5:277-298

13. Appadurai A (1996) Modernity at large. University of Minnesota Press, Minnesota

14. Vertovec S (2007) Super-diversity and its implications. Ethn Racial Stud 30:1024-1054. doi:10.1080/01419870701599465

15. Saybașilı N (2011) Waiting as potentiality. Third Text 25:356-362

16. Stepken A (2004) Anny and Sibel Öztürk in conversation with Angelika Stepken. In: Stepken A (ed) Sisters and brothers and birds. Karlsruhe

17. von Uslar R (2010) Anny \& Sibel Öztürk. In: von Uslar R (ed) At home, wherever. Yap1 Kredi Publications, Istanbul

18. Gökarkksel B, Secor A (2012) Even I was tempted: the moral ambivalence and ethical practice of veiling-fashion in Turkey. Ann Assoc Am Geogr 102:847-862. doi:10.1080/00045608.2011.601221

19. Bishop C (2012) Artificial hells: participatory art and the politics of spectatorship. Verso Books, London

20. Göle N (1996) The forbidden modern: civilization and veiling. University of Michigan Press, Ann Arbor

21. Secor A (2002) The veil and urban space in Istanbul: women's dress, mobility, and Islamic knowledge. Gend Place Cult 9:5-22. doi:10.1080/09663690120115010 
22. Gökarıksel B, Secor A (2010) Islamic-ness in the life of a commodity: veiling-fashion in Turkey. Trans Inst Br Geogr 35:313-333. doi:10.1111/j.1475-5661.2010.00384.x

23. Tiravanija R (1995) Surface de réparations: John Armleder, Henry Bond, Angela Bulloch, Jason Fox, Liam Gillick, Carsten Höller, Pierre Huyghe, Jim Isermann, Pierre Joseph, Philippe Parreno, Jennifer Pastor, Simon Patterson, Rirkrit Tiravanija, Lily van der Stokker, Xavier Veilhan. Frac de Bourgogne, Dijon

24. Bal M (2008) Double movement. In: Mieke B, Hernandez-Navarro M (eds) 2Move: video art migration. Cendeac, Murcia, pp 13-80

25. Fabian J (2002) Anthropology with an attitude: critical essays. Stanford University Press, Stanford
26. Fowler S (2011) Modern women artists in Turkey meet their trailblazing counterparts. In: The New York Times, published on December 14, 2011

27. Şirin D (2013) Yatak Odasında Müsabaka. Sanat Dünyamız 136:70

28. Interview by Karin Meisel with Nilbar Güreș after the exhibition "The Seen and the Hidden: Discovering the Veil at the Austrian Cultural Forum". New York (22 May- 29 August, 2009)

29. Hannerz U (1996) Transnational connections. Culture, people, places. Routledge, London

30. Beck U, Giddens A, Lash S (1994) Reflexive modernization: politics, tradition and aesthetics in the modern social order. Stanford University Press, Stanford 